\title{
Gender differences related to the health and lifestyle patterns of university students
}

\author{
Authors: \\ Christine Janse van Rensburg ${ }^{1}$ \\ Jhalukpreya Surujlal ${ }^{2}$ \\ Affiliations: \\ ${ }^{1}$ Faculty of Management \\ Sciences, Vaal University of \\ Technology, South Africa \\ ${ }^{2}$ Faculty of Economic \\ Sciences and IT, North-West \\ University, South Africa

\section{Correspondence to:} \\ Christine Janse van Rensburg \\ Email: \\ christinevr@vut.ac.za \\ Postal address: \\ Vaal University of \\ Technology, Human Resource \\ Management, Private Bag \\ X021, Vanderbijlpark 1900, \\ South Africa \\ Dates: \\ Received: 14 Mar. 2013 \\ Accepted: 21 Aug. 2013 \\ Published: 04 Oct. 2013 \\ How to cite this article: \\ Janse van Rensburg, C. \& \\ Surujlal, J., 2013, 'Gender \\ differences related to the \\ health and lifestyle patterns \\ of university students', \\ Health SA Gesondheid 18(1), \\ Art. \#735, 8 pages. http:// \\ dx.doi.org/10.4102/hsag. \\ v18i1.735

\section{Copyright:} \\ (C) 2013. The Authors. \\ Licensee: AOSIS \\ OpenJournals. This work \\ is licensed under the \\ Creative Commons \\ Attribution License.

One of the transitions from adolescence to adulthood is the admission of students to a university setting. Accompanying this transition is a new-found independence which results in university students having more autonomy over their lifestyles and behaviours. The assumption in this setting is that many students are likely to engage in unhealthy and risky lifestyle behaviours which include alcohol abuse, tobacco use, physical inactivity and unhealthy dietary practices which may adversely affect their health in the long-term. In South Africa, research with regard to health and lifestyle patterns amongst both male and female young adults remains limited. The purpose of this study was, therefore, to investigate whether male and female students differed in relation to their health and lifestyles, as well as the related consequences thereof. A convenience sampling technique was used, where questionnaires were administered to 400 students at three university campuses in the Gauteng province of South Africa. An exploratory data analysis for health factors was used in order to retrieve relevant factors from a factor and regression analysis. Differences in gender were tested by using cross-tabulation for descriptive statistics and Chi-square analysis. The study found no statistically-significant differences between genders relating to the three emerging health factors, namely Gastrointestinal, Upper Respiratory Infections and Total Health Problems. However, descriptive statistics of lifestyle habits revealed that more female students exercised, smoked and binged on food than their male counterparts. It was also found that female students reported a higher incidence of stress than male students. It was concluded that university students do indeed engage in behaviours and lifestyles that place them at risk for serious health problems.

In die oorgang van adolessensie na jong volwassene, bevind studente hulself binne 'n universiteitsomgewing. Gepaartgaande met hierdie oorgang word nuutgevonde vryheid verkry, wat veroorsaak dat universiteitstudente meer beheer oor hul lewenstyl en gedrag uitoefen. Die waarskynlikheid bestaan dat baie studente in hierdie omgewing betrokke sal raak by 'n ongesonde en gewaagde lewenstyl, wat alkohol misbruik, tabak gebruik, fisieke onaktiwiteit en ongesonde eetgewoontes insluit. Bogenoemde is faktore wat student se gesondheid oor die langtermyn nadelig sal beïnvloed. Navorsing in Suid-Afrika oor gesondheid en lewenstylpatrone van verskillende geslagsgroepe onder jong volwassenes is skaars. Die doel van hierdie studie was dus om ondersoek in te stel aangaande geslagsverskille in gesondheid en lewenstyl van studente, asook die betrokke nagevolge daarvan. 'n Gerieflikheidssteekproeftegniek is gebruik waartydens 400 vraelyste aan studente by drie verskillende universiteitskampusse in die Gauteng provinsie in Suid-Afrika versprei is. 'n Ondersoekende data analiese vir gesondheidsfakore is gebruik om toepaslike faktore te verkry vanuit' $n$ faktoren regressie analiese. Geslagsverskille is getoets deur gebruik te maak van kruis-tabulering vir beskrywende statistiek asook 'n 'Chi-square' analiese. Die studie het geen statistiesbetekenisvolle verskille tussen geslagte getoon ten opsigte van die drie gesondheidsfaktore naamlik Gastro-intestinale, Boonste Asemhalingstelsel en Totale Gesondheid Probleme nie. Nietemin het beskrywende statistiek ten opsigte van lewenstyl gewoontes egter onthul dat meer vroulike studente aan fisieke aktiwiteit delneem, rook en hul vergryp aan kos. Daar is ook gevind dat vroulike studente meer gevalle van spanning gerapporteer het as manlike studente. Die gevolgtrekking is dus dat universiteitstudente wel betrokke raak by gedrag en lewenstyle wat hul in gevaar stel vir ernstige gesondheidsprobleme.

\section{Introduction}

The leading causes of global deaths today are largely lifestyle related (World Health Organization [WHO] 2013a). A healthy lifestyle is an important predictor of future health, productivity and life expectancy. It has been found to reduce the factors which contribute to health risks (Fahey, Insel \& Roth 2009:3-4).

Global risks (WHO 2011a:16) for mortality are indicated as high blood pressure (13\%), tobacco use $(9 \%)$, high blood glucose $(6 \%)$, physical inactivity $(6 \%)$ and being overweight and obese 
(5\%). These risks are associated with increased chances of contracting any of the four main non-communicable diseases (NCD), namely cardiovascular disease, diabetes, chronic lung diseases and cancers, which affect individuals across all income groups in different countries (WHO 2013a).

Statistics from the World Health Organization (WHO 2013b) further indicated that during 2008 approximately $54 \%$ percent of all deaths globally were caused by the four main NCDs. In Europe these fatalities added up to $77 \%$, the United States of America 57\%, Africa 27\% and South Africa 25\% (WHO 2013b, 2013c). More recent statistics on South Africa revealed that the rising burden of NCDs is shown by an increase in deaths due to cardiovascular diseases $(11 \%)$, cancers $(7 \%)$, respiratory diseases $(3 \%)$, diabetes $(3 \%)$ and other NCDs (4\%), which account for $28 \%$ of all fatalities (WHO 2011b:1).

Most of the fatalities are linked closely to health-risk behaviours that are categorised in six areas: behaviours that contribute to unintentional and intentional injuries; tobacco use; alcohol and other drug use; sexual behaviours; unhealthy dietary behaviours; and physical inactivity (Mayosi et al. 2009:936). Health risks can be countered by a healthier lifestyle which includes regular physical activity, proper nutrition, elimination of unhealthy behaviours, having regular medical check-ups and maintaining good emotional health (Hoeger \& Hoeger 2010:9). Hence, it is logical to assume that most of these reported deaths could have been prevented through healthier lifestyles.

Global trends indicate a movement toward more unhealthy behaviours and lifestyles. According to Janse van Rensburg, Surujlal and Dhurup (2011:249), the increased adoption of Western world lifestyle habits during the 1900s resulted in a decrease in healthier lifestyles and an increase in related diseases in the global community. University students represent a major percentage of the young adult population of this global community (Von Bothmer \& Fridlund 2005:107). Thus, an increase in unhealthy behaviours will also affect the student population.

\section{Lifestyle behaviour of university students}

Transition for young adults from high school to the university setting represents a major step toward personal independence and freedom from direct parental supervision (Keller et al. 2008:189; Surujlal, Nolan \& Ubane 2012:281). Although exciting, this event also presents as a stressful experience as these young adults need to adapt to changes in their lifestyles. These changes may include increased academic workloads, new environments and financial- and social pressures (Edlin \& Golanty 2012:16; Pettay 2008:1, 7). Research (Janse van Rensburg et al. 2011:258-259) also indicates that university students experience greater social pressures during their university studies compared with their high school years. These social pressures in their new social groups influence them to conform to perceived new and acceptable behaviours, in an environment where the use of intoxicating substances is culturally acceptable (Goga 2010:46).
New behaviours and lifestyle patterns formed during university life are likely to be sustained into adulthood (Takomana \& Kalimbira 2012:132). Lifestyle patterns could include various risky behaviours such as alcohol use, tobacco use, physical inactivity and unhealthy dietary practices (Keller et al. 2008:189-190; Pettay 2008:1). Other risky behaviours may include ignoring preventive safety habits such as wearing seat belts, excessive sun exposure (Von Ah et al. 2004:463) and risky sexual behaviours such as multiple sexual partners (Laska et al. 2009:377). The current study focused on risky behaviours such as alcohol use, tobacco use, physical inactivity and the dietary practices of university students.

Excessive alcohol use amongst university students is a widespread problem at many campuses and can result in liver disease, damage to the nervous system and an increased risk of cancer (George et al. 2013:96). Over and above the health risks, the consumption of alcohol at universities also contributes to problems such as students engaging in violent behaviour, damaging property and missing classes because of hangovers. Research suggests a direct correlation between the quantities of alcohol consumed and lowered academic performance (Brister 2012:5). Goldstein and Flett (2009:183) argue that students drink as an emotional response and to modulate either positive (i.e. enhancement of positives) or negative (i.e. coping motives) experiences.

Tobacco use in all its forms is considered a major threat to life as smoking increases the chances of dying prematurely from heart attack, several types of cancer, bronchitis, pneumonia, stroke and may even deplete the energy levels required to cope with daily activities (Edlin \& Golanty 2009:11-12). Studies (Gasparotto et al. 2013:687; Laska et al. 2009:377; Oktay, Çelik \& Akbaba 2013:175) have revealed that smoking is highly prevalent amongst students worldwide, which significantly increases their chance of premature mortality.

Physical inactivity is on the increase as students participate less in physical exercise (Nolan, Sandada \& Surujlal 2011:56). It has been associated with increased risk of cardiovascular disease, various cancers, obesity and other health problems (Thygerson \& Thygerson 2013:2, 6). Physical inactivity amongst students can be attributed to the fact that students have become immersed in technology in nearly all aspects of their everyday living. This includes the usage of computers, cell phones, the Internet, iPods and sedentary entertainment, such as television, video and computer programs (Edlin \& Golanty 2009:27; Terzian \& Moore 2009:1; Toscos et al. 2008:218). Increased attention and participation in such activities may lead to decreased levels of participation in physical activity.

Unhealthy dietary practices which can be the cause of overweight and obesity, are associated with a number of disabling and potentially fatal conditions and diseases, including heart disease, cancer, diabetes and high blood pressure (Edlin \& Golanty 2012:12). University students' eating behaviours are influenced by their peers and the 
media, as well as the fact that fast food and vending machines are readily available on campus (Dalton 2013:11-16; Spanos \& Hankey 2010:102). Deshpande, Basil and Basil (2009:147) suggest that the university environment may also play a significant role in the worsening of dietary habits amongst students. This may arise because of the limited choice of food types available, the cost of food, the convenience of eating out instead of preparing their own meals and the academic timetables to which they are required to adhere (Pedersen \& Ketcham 2009:465; Van Zyl, Surujlal \& Dhurup 2012: 276-277).

The inability to cope with stress may also contribute to unhealthy practices such as excessive eating, drinking and smoking by students (Surujlal et al. 2012:283; Van Zyl et al. 2012:268). Students often lack the strong social support networks and coping skills needed in order to handle stress effectively (Van Zyl et al. 2012:268-270). Poor management of stress can lead to cancer, migraines, ulcers, digestive problems, insomnia, hypertension or heart attacks (Edlin \& Golanty 2012:44; Fahey et al. 2009:309-310).

The aforementioned unhealthy habits and behaviours, causing morbidity and/or mortality in Western society, are behaviour-related and are therefore preventable if identified and changed at an early stage. It is thus important to gain a general understanding of the lifestyle patterns present in university students, in order to assist them to prevent premature mortality or unnecessary morbidity. Healthier lifestyles may aid students in becoming productive citizens for the future of South Africa.

\section{Problem statement}

Entering university is an exciting and challenging time for young people. It is interlinked with changes and new-found responsibilities such as greater control over their lifestyle and exploration of lifestyle choices. University years may also be seen as a unique opportunity to develop a healthy lifestyle or to shape lifestyle behaviours in a positive manner. Fahey et al. (2009:6) point out that a lifestyle based on healthy behaviours maximises the quality of life by helping people to avoid disease, remain strong and fit and maintain their physical and mental health. This implies that healthy choices today may influence health for the rest of one's life.

There is, however, evidence that many students engage in various unhealthy and risky lifestyle behaviours, such as inadequate nutritional intake, decreased sleep and exercise, increased smoking and substance abuse and other negative practices, which may produce long-term adverse effects on their health (Edlin \& Golanty 2012:16; Pettay 2008:1-3).

Literature (Keller et al. 2008:190; Laska et al. 2009:376) indicates that young people are an under-researched group with regard to their health and lifestyle patterns. Only a few surveys of the health of students at universities and other higher-education institutions exist, particularly in a South African setting. As a result, information about students' health is scarce.
Investigation of university students' health and lifestyle patterns is therefore essential, especially in the South African population of university students, as they have been neglected in health and lifestyle pattern research. It is also evident from previous research that, in many instances, not enough attention is paid to gender differences in relation to university students' lifestyle and the creation of awareness of healthy lifestyle behaviour for South African university students.

Consequently, the purpose of this study was to investigate gender differences in students' health and lifestyles in order to contribute to the existing knowledge of lifestyle behaviours of university students and to make recommendations on the findings. Specifically the study addressed the following research questions:

1. Are there any statistically-significant gender differences based on the following variables: Gastrointestinal, Upper Respiratory Infections and Total Health Problems?

2. Are there any differences according to gender regarding the lifestyle habits of the respondents?

\section{Research method and design}

An extensive literature study on university students' health and lifestyle patterns was conducted when undertaking the current study. In addition, an empirical investigation involving the administration of 400 wellness questionnaires was undertaken. A cross-sectional survey design was used to make inferences about the health and lifestyle patterns of students at selected university campuses.

\section{Sample and procedure}

A convenient sample of 400 second-year, third-year and post-graduate students at three university campuses in the Gauteng province of South Africa formed the sample of the study. First-year students were excluded from the study as it was expected that these students would still be adjusting to their new academic environment and may not have sufficient experience of the university setting and life to make a meaningful contribution to the study. The services of academics who were associated closely with students at the different universities were enlisted to administer the questionnaire to students during class sessions. The questionnaire was administered over a period of two weeks. Of the 400 university students who were approached to participate in the study, 381 (95\%) completed the questionnaire. For the sake of anonymity, the universities are listed as University A, University B and University C and the results are presented in aggregate.

\section{Instrument}

An adapted version of the 'Student health and lifestyle questionnaire' (Engs 1992) was used. The lifestyle questionnaire was designed to test lifestyle behaviours and is based on a survey instrument that had been used previously (Engs et al. 1990; Engs \& Hanson 1994). In Section A, the 'year of study' was included and the 'race' category was adapted to the 
South African ethnic groups. The race groups in South Africa differed from those in the original questionnaire, therefore this part of the questionnaire was changed to suit the South African context. In Section B, the 'mono' category was excluded due to the fact that this is not a widely-used term in South Africa and could cause confusion. No adjustments were made to the questions in Section C. The questionnaire comprised three sections. Section A requested demographic information of the respondents, Section B requested information on health problems experienced by respondents and Section $C$ requested information on the lifestyle habits of respondents. The questions in this section were survey-type questions, for instance: 'How many times did you exercise during the past month? During the past month, how many times did you drink beer?'

The current article reports on the health and lifestyle patterns of university students.

\section{Data analysis}

The data were captured and analysed using the Statistical Package for the Social Sciences (SPSS) version 17. The analysis was as follows:

- Firstly, descriptive statistics were conducted to describe the demographic profile of the respondents.

- Secondly, the demographic variables versus health factors were analysed through inferential statistics with the usage of either the independent $t$-test or the analysis of variance (ANOVA).

- Thirdly, the lifestyle habits per gender group were analysed using cross-tabulation tables together with the Chi-square statistic.

\section{Results}

The demographic composition of the respondents is presented in Table 1. An examination of the demographic profile indicated that more female students $(269 ; 70.8 \%)$ than male students $(111 ; 29.2 \%)$ responded to the questionnaire. The majority of respondents were between 18 and 27 years of age $(355 ; 93.4 \%)$. Most respondents $(258 ; 68.1 \%)$ were African students with the least $(12 ; 3.2 \%)$ being Coloureds and Indian or Asians. The minority of respondents were living on campus $(81 ; 21.5 \%)$, with others living off campus without

TABLE 1: Demographic information of student respondents.

\begin{tabular}{lllll}
\hline Variable & Categories & $\boldsymbol{N}$ & $\boldsymbol{n}$ & $\mathbf{\%}$ \\
\hline Gender & Male & 380 & 111 & 29.2 \\
& Female & 380 & 269 & 70.8 \\
Age & $18-27$ & 380 & 355 & 93.4 \\
& $28-37$ & 380 & 19 & 5.0 \\
Race & $38-47$ & 380 & 6 & 1.6 \\
& African people & 379 & 258 & 68.1 \\
& Coloured people & 379 & 12 & 3.2 \\
& Indian/Asian people & 379 & 12 & 3.2 \\
Living & White people & 379 & 97 & 25.6 \\
arrangements & Off campus without parents & 377 & 157 & 41.6 \\
& Off campus with parents & 377 & 139 & 36.9 \\
Year of study & On campus & 377 & 81 & 21.5 \\
& 2nd year & 379 & 160 & 42.2 \\
& 3rd year & 379 & 147 & 38.8 \\
& Post graduate & 379 & 72 & 19.0 \\
\hline
\end{tabular}

their parents $(157 ; 41.6 \%)$ or off campus with their parents $(139 ; 36.9 \%)$. A total of 160 students $(42.2 \%)$ was studying at the second-year level, 147 students $(38.8 \%)$ at the thirdyear level and $72(19.0 \%)$ were enrolled for a post-graduate qualification.

To calculate a health problem score, students were asked to indicate how many times they had experienced a given health problem during the previous month. Three factors were retrieved from factor and regression analysis. Aspects clustered in the Gastrointestinal category included upset stomach, nausea or vomiting and diarrhoea. The Upper Respiratory Infections cluster included sore throat, a cold or flu, cough, bronchitis or laryngitis and ear infection. Symptoms included in General Malaise are headache and lack of energy. The Total Health Problems, comprising the aforementioned three factors, indicated a weighted health score of 21315 . Higher scores are indicative of higher levels of health problems.

Frequency responses of Section B were recorded and statistically-significant difference levels are indicated in Table 2 .

Statistically-significant differences were found for gender based on the following variables: Gastrointestinal, Upper Respiratory Infections and Total Health Problems. Male students experienced lesser symptoms of Gastrointestinal, Upper Respiratory Infections and Total Health Problems than female students, based on the comparison of the averages in Table 3.

The differences in gender were ascertained by using crosstabulations for descriptive statistics and Chi-square testing significance.

Based on exercise sessions per month, female respondents exercised more than males, except in the 15-21 times frequency category, where the frequencies for male and female are similar. With regard to stress, the results indicate that female students experience more stress than male students. The alcohol-consumption pattern shows that male students are inclined to consume more beer and hard liquor, whilst female students preferred beer, wine and wine coolers. An interesting finding regarding alcohol consumption was that between $40 \%$ and $50 \%$ of female students and $15 \%$ to $20 \%$ male students indicated that they do not drink any beer, wine, wine coolers or hard liquor at all. A higher percentage of females than males used tobacco. More female than male students binged on food.

\section{Ethical considerations}

Permission to use the questionnaire was obtained from the author. Written consent was obtained from the universities to conduct the study. A covering letter explaining the purpose of the study and assuring the respondents of anonymity and confidentiality was included with the questionnaire. Respondents were also informed that participation in the study was completely voluntary and that they could withdraw from the study at any stage. 
TABLE 2: Demographic variables versus health factors.

\begin{tabular}{|c|c|c|c|c|c|c|c|c|c|c|c|c|}
\hline \multirow[t]{2}{*}{ Demographic variables } & \multicolumn{3}{|c|}{ Gastrointestinal } & \multicolumn{3}{|c|}{ Upper Respiratory Infections } & \multicolumn{3}{|c|}{ General Malaise } & \multicolumn{3}{|c|}{ Total Health Problems } \\
\hline & Mean & Std Dev & Sig. & Mean & Std Dev & Sig. & Mean & Std Dev & Sig. & Mean & Std Dev & Sig. \\
\hline \multicolumn{13}{|l|}{ Gender } \\
\hline Male & 1.17 & 3.159 & \multirow{2}{*}{$0.000^{*}$} & 2.48 & 3.653 & \multirow{2}{*}{$0.008^{*}$} & 3.68 & 7.484 & \multirow{2}{*}{0.056} & 9.575 & 14.0469 & \multirow{2}{*}{$0.000^{*}$} \\
\hline Female & 3.28 & 6.905 & & 4.22 & 9.034 & & 14.94 & 61.612 & & 26.122 & 64.3214 & \\
\hline \multicolumn{13}{|l|}{ Age } \\
\hline $18-27$ & 2.80 & 6.296 & \multirow{3}{*}{0.248} & 3.91 & 8.114 & \multirow{3}{*}{0.170} & 12.06 & 53.897 & \multirow{3}{*}{0.785} & 22.139 & 56.8389 & \multirow{3}{*}{0.504} \\
\hline $28-37$ & 0.95 & 2.223 & & 0.89 & 1.595 & & 3.53 & 5.938 & & 7.326 & 7.2764 & \\
\hline $38-47$ & 0.00 & 0.000 & & 0.67 & 0.816 & & 13.17 & 25.191 & & 15.200 & 25.3401 & \\
\hline \multicolumn{13}{|l|}{ Race } \\
\hline African & 2.82 & 6.587 & \multirow{4}{*}{0.481} & 3.56 & 6.805 & \multirow{4}{*}{0.832} & 7.89 & 10.672 & \multirow{4}{*}{0.14} & 17.610 & 21.2666 & \multirow{4}{*}{0.194} \\
\hline Coloured & 4.42 & 8.898 & & 2.58 & 3.370 & & 10.67 & 16.272 & & 21.875 & 26.3194 & \\
\hline Indian/Asian & 1.25 & 2.417 & & 3.67 & 3.869 & & 7.92 & 10.791 & & 15.250 & 15.3030 & \\
\hline White & 2.14 & 4.585 & & 4.30 & 10.859 & & 22.20 & 101.313 & & 31.656 & 102.6287 & \\
\hline \multicolumn{13}{|l|}{ Living arrangements } \\
\hline $\begin{array}{l}\text { Off campus, } \\
\text { with parents }\end{array}$ & 3.25 & 7.036 & \multirow[t]{2}{*}{0.346} & 4.48 & 10.280 & \multirow[t]{2}{*}{0.214} & 18.91 & 84.766 & \multirow[t]{2}{*}{0.117} & 30.347 & 86.9652 & \multirow[t]{2}{*}{0.049} \\
\hline On campus & 2.36 & 6.643 & & 2.54 & 4.458 & & 6.53 & 8.778 & & 14.401 & 17.2476 & \\
\hline \multicolumn{13}{|l|}{ Year of study } \\
\hline 2nd year & 2.86 & 5.850 & \multirow{3}{*}{1.074} & 3.68 & 7.365 & \multirow{3}{*}{0.007} & 9.19 & 12.307 & \multirow{3}{*}{0.802} & 19.107 & 22.1966 & \multirow{3}{*}{0.885} \\
\hline $3 r d$ year & 2.88 & 7.330 & & 3.65 & 8.616 & & 15.91 & 82.427 & & 25.837 & 84.4924 & \\
\hline Post graduate & 1.69 & 3.418 & & 3.78 & 7.531 & & 8.42 & 13.559 & & 16.583 & 18.9921 & \\
\hline
\end{tabular}

Notes: Sig., significance; ${ }^{*}$, Statistically-significant difference at 0.05 .

TABLE 3: Lifestyle habits per gender group.

\begin{tabular}{|c|c|c|c|c|}
\hline Item & Frequency & Male (\%) & Female (\%) & Sig \\
\hline \multirow[t]{4}{*}{ How many times did you exercise during the past month? } & 1 to 7 times & 14.6 & 31.5 & \multirow{4}{*}{$0.001^{*}$} \\
\hline & 8 to 14 times & 8.3 & 20.7 & \\
\hline & 15 to 21 times & 7.3 & 7.0 & \\
\hline & 22 times and more & 1.0 & 9.6 & \\
\hline \multirow{4}{*}{$\begin{array}{l}\text { How many times did you feel 'stressed out' (under stress) during } \\
\text { the past month? }\end{array}$} & 1 to 7 times & 19.5 & 36.6 & \multirow{4}{*}{$0.002^{*}$} \\
\hline & 8 to 14 times & 5.3 & 18.6 & \\
\hline & 15 to 21 times & 1.2 & 5.3 & \\
\hline & 22 times and more & 1.2 & 12.4 & \\
\hline \multirow[t]{4}{*}{ During the past month, how many times did you drink beer? } & Less than 3 times a week & 6.0 & 4.1 & \multirow{4}{*}{$0.000^{*}$} \\
\hline & Once a week & 4.9 & 8.8 & \\
\hline & At least once a month, but less than once a week & 6.3 & 11.3 & \\
\hline & Not at all & 12.1 & 46.4 & \\
\hline \multirow{4}{*}{$\begin{array}{l}\text { During the past month, how many times did you drink wine or a } \\
\text { wine cooler? }\end{array}$} & Less than 3 times a week & 1.7 & 2.8 & \multirow{4}{*}{0.068} \\
\hline & Once a week & 3.4 & 10.1 & \\
\hline & At least once a month, but less than once a week & 3.9 & 17.0 & \\
\hline & Not at all & 20.7 & 40.5 & \\
\hline \multirow{4}{*}{$\begin{array}{l}\text { During the past month, how many times did you drink hard } \\
\text { liquor (vodka, rum, whiskey, etc.)? }\end{array}$} & Less than 3 times a week & 2.0 & 1.7 & \multirow{4}{*}{$0.000^{*}$} \\
\hline & Once a week & 4.8 & 3.7 & \\
\hline & At least once a month, but less than once a week & 7.4 & 14.7 & \\
\hline & but less than once a week & 15.3 & 50.4 & \\
\hline \multirow[t]{3}{*}{ During the past month, how many days did you use tobacco? } & 1 to 5 times & 12.5 & 19.4 & \multirow{3}{*}{0.724} \\
\hline & 6 to 10 times & 2.8 & 8.3 & \\
\hline & More than 10 times & 18.1 & 38.9 & \\
\hline \multirow[t]{3}{*}{ How many days did you binge out on food? } & 1 to 5 times & 26.8 & 48.2 & \multirow{3}{*}{$0.042^{*}$} \\
\hline & 6 to 10 times & 0.9 & 8.0 & \\
\hline & More than 10 times & 1.8 & 14.3 & \\
\hline
\end{tabular}

Sig, significance; *, Statistically-significant difference at 0.05 .

\section{Validity and Reliability}

Validity was accepted a priori in this study. This is because the development and determination of the factor structure of the scale was adequately described by Engs (1992). The reliability for the instrument was 0.741 , which was higher than the recommended acceptable level of 0.7 suggested by Nunnally (1978:245); and in line with the reliability (Cronbach alpha $=0.89)$ as was determined in the original study. 


\section{Discussion}

It is evident from the results that many university students have a tendency to engage in behaviours and lifestyles that place them at risk for serious health problems. Similar to Engs and Aldo-Benson's (1995:731) findings, Gastrointestinal and Upper Respiratory Infections also emerged in this study as a health problem experienced by students. On the other hand, contrary to the study by Engs and AldoBenson (1995:731), which reported no statistically-significant differences between genders relating to Gastrointestinal, Upper Respiratory Infections and Total Health Problems, the current study found statistically-significant differences in all three categories.

A close examination of the descriptive statistics regarding the lifestyle habits of females revealed that they exercise more than their male counterparts. This finding contradicts that of Al-Otaibi, Nassef and Raouf (2013:619), whose study reported that more male students than female students engaged in physical activity. A plausible reason for higher participation levels by female students in this study may be that at this age female students are more conscious of their appearance and as a result they tend to exercise more. Szabo and Allwood (2006) found, in their comparison of Black and White adolescent females in South Africa, that urban Black females were closer to urban White females than were rural Black females regarding their body figure preference to be thinner. It is also possible that during this time males tend to compete with their peers in terms of their image and lifestyle patterns and they might be more prone to engage in other behaviours that are seen as acceptable in the male student domain, such as drinking or smoking. This finding, however, is in stark contrast to that of Nolan and Surujlal (2012:328) who found that male students focused more on their fitness than female students.

Female students reported a higher occurrence of stress than male students. This result concurs with the findings of Laska et al. (2009:380) and Von Bothmer and Fridlund (2005:112). This finding may also explain why more female students participate in exercise, as it has been found that one of the benefits of exercise is to reduce levels of stress (Nolan \& Surujlal 2009:10). In their study, Thawabieh and Qaisy (2012:116) also found that female students experienced more stress than male students. They attributed this to the fact that females are more subject to community pressure, as well as the pressure of their cultural habits.

More female students than male students did not consume any alcohol. This corresponds with research done by Kremer and Levy (2008:196). A possible reason for this could be that males are more susceptible to peer influences than female students. The authors, however, argue that because more drinking takes place in male dorm rooms at universities, the propensity for male students to consume alcohol was greater. Another factor that could contribute to higher alcoholconsumption patterns in male students is that they are more likely to attend a greater number of parties where alcohol is consumed than female students.
The finding that more female students used tobacco is in agreement with that of Laska et al. (2009:380). However, research done by Thompson et al. (2007:429) and Von Bothmer and Fridlund (2005:112) diverge by indicating that more males are likely to use tobacco than females.

The finding that more female students binged on food is in contrast with research from Mwaba and Roman (2009:908), where Black South African female students indicated that, irrespective of their body shape, they engaged in healthy eating behaviours. In a study by Senekal, Steyn \& Nel (2003:111), however, it was found that a large proportion of Black women in South Africa were overweight and obese. Similarly, Peltzer and Pengpid (2012:4513) confirmed a high prevalence of obesity in Black female students through their study done at a South African university. These findings corroborate those of Nelson and Story (2009) who said that university life, for most students, was characterised by poor eating habits. In another study, Gillen and Lefkowitz (2012:126), found that the poor eating habits made university students vulnerable to weight gain.

\section{Limitations and implications for further research}

The results reflected in this study are not representative of all the race groups. In view of this limitation, generalisation of the results of the study to all populations should be approached with caution. Despite this limitation, the study, however, provides interesting avenues for future research. For instance, the study could be replicated with a sample which is representative of all population groups so that comparisons can be made not only by gender but also across different population groups.

\section{Recommendations}

Arising from the study are recommendations which may assist in improving the lifestyle behaviours of university students. Stakeholders involved in academic planning, residence management, student services, student counselling, health education, physical education, recreational sports, food services and campus security could get together to develop comprehensive wellness programmes to guide and assist students toward a healthier lifestyle. If possible, aspects of such programmes should be integrated into the curriculum or orientation so that they become compulsory components.

In addition, ongoing awareness campaigns regarding the benefits of following a healthy lifestyle and highlighting the negative effects of engaging in unhealthy lifestyle behaviours should be undertaken. Counseling should be available for those students who are unable to take control of their lifestyle behaviours.

\section{Conclusion}

It appears from the results of the current study that university students engage in unhealthy lifestyles and risky behaviours 
which have implications for their future health. The results of the study indicate that statistically-significant differences were found for gender based on Gastrointestinal, Upper Respiratory Infections and Total Health Problems. The study also revealed gender differences in lifestyle patterns. Universities, as potential settings for health promotion in the early years of adulthood, need to take cognisance of the challenges that university students face as well as their naïvety with regard to healthy lifestyle behaviours so that appropriate measures can be taken to help direct them toward these behaviours.

\section{Acknowledgements Competing interests}

The authors declare that they have no financial or personal relationship(s) that may have inappropriately influenced them in writing this article.

\section{Authors' contributions}

C.J.v.R. (Vaal University of Technology) was the primary author responsible for the data collection, literature review and contributed jointly to the preparation of the manuscript. J.S. (North-West University) was responsible for the literature review, interpretation and reporting of the data and contributed jointly to the preparation of the manuscript.

\section{References}

Al-Otaibi, H.H., Nassef, S.L. \& Raouf, T.A., 2013, 'Body shape dissatisfaction, weight status and physical activity among a sample university students in Saudi Arabia', Food and Nutrition Sciences 4, 616-625. http://dx.doi.org/10.4236/ fns.2013.46079

Brister, H.A., 2012, 'Increasing emotion regulation skills for the reduction of heavy drinking', Phd thesis, Department of Psychology, Faculty of the Graduate School, University of Texas, Austin.

Dalton, K.A., 2013, 'Students' consumption of healthy food items using a social marketing intervention', Master's thesis, Department of Counseling and Student Development, Eastern Illinois University.

Deshpande, S. Basil, M.D. \& Basil, D.Z., 2009, 'Factors influencing healthy eating habits among college students: an application of the health belief model', Health Marketing Quarterly 26(2), 145-164. http://dx.doi.org/10.1080/07359680802619834 PMid:19408181

Edlin, G. \& Golanty, E., 2009, Health and Wellness, 10th edn., Jones \& Bartlett, Burlington.

Edlin, G. \& Golanty, E., 2012, Health and Wellness, 11th edn., Jones \& Bartlett, Burlington.

Engs, R.C., 1992, Student Health and Lifestyle questionnaire, Indiana University, Bloomington. PMid:1529075

Engs, R.C. \& Aldo-Benson, M., 1995, 'The association of alcohol consumption with self-reported illness in university students', Psychological Reports 76(3 Pt 1), 727736. http://dx.doi.org/10.2466/pro.1995.76.3.727, Mid:7568584

Engs, R.C. \& Hanson, D.J., 1994, 'The Student Alcohol Questionnaire: an updated reliability of the drinking patterns, problems, knowledge, and attitude subscales', Psychological Reports 74(1), 12-14. http://dx.doi.org/10.2466/pro.1994.74.1.12 Psychological Repc

Engs, R.C., Hanson, D.J. Gliksman, L. \& Smythe, D., 1990, 'Influence of religion and culture on drinking behaviours: a test of hypotheses between Canada and the USA', British Journal of Addictions 85(11), 1475-1482. http://dx.doi. and the USA', British Journal of Addictions
org/10.1111/j.1360-0443.1990.tb01631.x

Fahey, T., Insel, P. \& Roth, W., 2009, Fit and Well, 8th edn., McGraw-Hill, New York.

Gasparotto, G.S., Gasparotto, L.P., Rossi, L.M., Moreira, N.B., Bontorin, M.D.S. \& De Campos, W., 2013, 'Association between moment of the undergraduate course and cardiovascular risk factors in university students', Revista LatinoAmericana de Enfermagem 21(3), 687-694. http://dx.doi.org/10.1590/S010411692013000300006, PMid:23918013

George, G.E., Mugai, W.J., Mugai, N.W., Mugai, W.F. \& Nyakwara, S., 2013, 'Socioeconomic factors on alcohol abuse among the youth in Kikuyu district, Kenya', Research on Humanities and Social Sciences 3(7), 96-109.
Gillen, M.M. \& Lefkowitz, E.S., 2012, 'Gender and racial/ethnic differences in body image development among college students', Body Image 9(1), 126-130. http:// image development among college students', Body Image 9(1), 126-130. http://
dx.doi.org/10.1016/j.bodyim.2011.09.004, PMid:21983339 PMCid:PMC3246027

Goldstein, A.L. \& Flett, G.L., 2009, 'Personality, alcohol use, and drinking motives: a comparisonofindependentand combinedinternaldrinkingmotivesgroups', Behavior Modification 33(2), 182-198. http://dx.doi.org/10.1177/0145445508322920 PMid:18836143

Goga, S., 2010, "Rhodes students love to get drunk': race, ritual and the legitimation of the authentic Rhodes student', South African Review of Sociology 41(2), 41-50. $\mathrm{http}: / / \mathrm{dx}$.doi.org/10.1080/21528586.2010.490382

Hoeger, W.K. \& Hoeger, S.A., 2010, Fitness and Wellness, Wadsworth, Belmont.

Janse van Rensburg, C., Surujlal, J. \& Dhurup, M., 2011, 'Exploring wellness practices and barriers: A qualitative study of university student-athletes', African Journal for Physical, Health Education, Recreation and Dance 17(2), 248-265.

Keller, S., Maddock, J.E., Hannöver, W., Thyrian, J.R. \& Basler, H., 2008, 'Multiple health risk behaviors in German first year university students', Preventative Medicine 46(3), 189-195. http://dx.doi.org/10.1016/j.ypmed.2007.09.008, PMid:18242666

Kremer, M. \& Levy, D., 2008, 'Peer effects and alcohol use among college students', Journal of Economic Perspectives 22(3), 189-206. http://dx.doi.org/10.1257/ jep.22.3.189

Laska, M.N., Pasch, K.E., Lust, K., Story, M. \& Ehlinger, E., 2009, 'Latent class analysis of lifestyle characteristics and health risk behaviors among college youth', Prevention Science 10(4), 376-386. http://dx.doi.org/10.1007/s11121-009-0140 2, PMid:19499339 PMCid:PMC2927491

Mayosi, B.M., Flisher, A.J., Lalloo, U.G. Sitas, F., Tollman, S.M. \& Bradshaw, D., 2009 'The burden of non-communicable diseases in South Africa', Lancet 374(9693), 934-947. http://dx.doi.org/10.1016/S0140-6736(09)61087-4

Mwaba, K. \& Roman, N.V., 2009, 'Body image satisfaction among a sample of black female South African students', Social Behavior and Personality 37(7), 905-909. http://dx.doi.org/10.2224/sbp.2009.37.7.905

Nelson, M.C. \& Story, M., 2009, 'Food environments in university dorms: 20,000 calories per dorm room and counting', American Journal of Preventative Medicine 36(6), 523-526. http://dx.doi.org/10.1016/j.amepre.2009.01.030, PMid:19356889

Nolan, V.T., Sandada, M. \& Surujlal, J., 2011 'Perceived benefits and barriers to physical exercise participation of first year university students', African Journal for Physical, Health Education, Recreation and Dance, September Supplement, 56-69.

Nolan, V.T. \& Surujlal, J., 2009, 'Assessment of working women's perception and pursuit of recreation', African Journal for Physical, Health Education, Recreation and Dance, September (Supplement), 1-15.

Nolan, V.T. \& Surujlal, J., 2012. 'Gender differences in body image perceptions of South African university students', African Journal for Physical, Health Education, Recreation and Dance, December (Supplement 1:2), 321-331.

Nunnally, J.C., 1978, Psychometric Theory, 2nd edn., McGraw-Hill, New York.

Oktay, E., Çelik, A.K. \& Akbaba, A.I., 2013, 'Examining demographic factors related to cigarette smoking among undergraduate students at a Turkish university', International Journal of Higher Education 2(2), 175-183.

Pedersen, P.J. \& Ketcham, P.L., 2009, 'Exploring the climate for overweight and obese students in a student health setting', Journal of American College Health 57(4), 465-469.

Peltzer, K. \& Pengpid, S., 2012, 'Body weight and body image among a sample of female and male South African university students', Gender and Behaviour 10(1) 4509-4522.

Pettay, R.F., 2008, 'Health behaviors and life satisfaction in college student', PhD thesis, Department of Counseling and Educational Psychology, Kansas State University.

Senekal, M., Steyn, N.P. \& Nel, J.H., 2003, 'Factors associated with overweight/obesity in economically active South African populations', Ethnicity \& Disease 13(1), 109116. PMid:12723019

Spanos, C. \& Hankey, C.R., 2010, 'The habitual meal and snacking patterns of university students in two countries and their use of vending machines', Journal of Human Nutrition and Dietetics 23(1), 102-107. http://dx.doi.org/10.1111/j.1365 277X.2009.01005.x, PMid:19943844

Surujlal, J., Nolan, V.T. \& Ubane, T., 2012, 'Drinking patterns and related consequences among university student-athletes', African Journal for Physical, Health Education, Recreation and Dance 18(2), 281-292.

Szabo, C.P. \& Allwood, C.W., 2006, 'Body figure preference in South African adolescent females: a cross cultural study', African Health Sciences 6(4), 201-206. PMid:17604508 PMCid:PMC1832064

Takomana, G. \& Kalimbira, A.A., 2012, 'Weight gain, physical activity and dietary changes during the seven months of first-year university life in Malawi', South African Journal of Clinical Nutrition, 25(3), 132-139.

Terzian, M. \& Moore, K.A., 2009, 'Physical inactivity in U.S. adolescents', Child Trends, Research brief 2009(28), 1-6.

Thawabieh, A.M. \& Qaisy, L.M., 2012, 'Assessing stress among university students', American International Journal of Contemporary Research 2(2), 110-116.

Thompson, B. Coronado, G., Chen, L., Thompson, L.A., Halperin, A., Jaffe, R. et al., 2007, 'Prevalence and characteristics of smokers at 30 Pacific Northwest colleges and universities', Nicotine \& Tobacco Research 9(3), 429-438. http://dx.doi. org/10.1080/14622200701188844, PMid:17365775 
Thygerson, A.L. \& Thygerson, S.M., 2013, Fit to be Well, 11th edn., Jones \& Bartlett Publishers, Burlington.

Toscos, T., Faber A., Connelly, K. \& Upoma, A.M., 2008, 'Encouraging physical activity in teens. Can technology help reduce barriers to physical activity in adolescent Conference, January 30-February 1, 2008, pp. 218-221.

Van Zyl, Y., Surujlal, J. \& Dhurup, M., 2012, 'Eating disorders among university studentathletes', African Journal for Physical, Health Education, Recreation and Dance 18(2), 267-280.

Von Ah, D., Ebert, S., Ngamvitroj, A., Park, N. \& Kang, D., 2004, 'Predictors of health behaviours in college students', Journal of Advanced Nursing 48(5), 463-474. http://dx.doi.org/10.1111/j.1365-2648.2004.03229.x, PMid:15533084

Von Bothmer, M.I. \& Fridlund, B., 2005, 'Gender differences in health habits and in motivation for a healthy lifestyle among Swedish university students' Nursing and Health Sciences 7(2), 107-118. http://dx.doi.org/10.1111/j.14422018.2005.00227 $x$ PMid:15877687
World Health Organization [WHO], 2011a, 'Global status report on noncommunicable diseases 2010', viewed 06 September 2013, from http://www.who.int/nmh/ publications/ncd report chapter1.pdf

World Health Organization [WHO], 2011b, 'World Health Organisation: NCD Country Profiles: South Africa, 2011', viewed 19 December 2012, from http://www.who. int/nmh/countries/zaf_en.pdf

World Health Organization [WHO], 2013a, 'Global Health Observatory: NCD mortality and morbidity', viewed 06 September 2013, from http://www.who.int/gho/ncd/ mortality_morbidity/en/index.html

World Health Organization [WHO], 2013b, 'Disease and injury regional estimates, 2004-2008, Cause-specific mortality: Regional estimates for 2008', viewed 06 September 2013, from http://www.who.int/healthinfo/global_burden_disease/ estimates_regional_2004_2008/en/

World Health Organization [WHO], 2013c, 'Global Health Observatory Data Repository, African Region: South Africa statistics summary (2002-present)',
viewed 06 September 2013, from http://apps.who.int/gho/data/node.country. country-ZAF?lang=en 